\title{
DAYA HAMBAT Trichoderma sp. TERHADAP PATOGEN YANG BERASOSIASI DENGAN DAUN TANAMAN TOMAT (Lycopersicum esculentum MILL.)
}

\author{
Asniah $^{1^{\star}}$, Wahyuni $^{1)}$, Muhammad Taufik ${ }^{1)}$ \\ ${ }^{1} J u r u s a n$ Proteksi Tanaman Fakultas Pertanian Universitas Halu Oleo Kendari 93232
}

${ }^{\star}$ Corresponding author: asniahkdi3@gmail.com

To cite this article:

Asniah, A., Wahyuni, W., \& Taufik, M. (2021). Daya Hambat Trichoderma sp. terhadap Patogen yang Berasosiasi dengan Daun Tanaman Tomat (Lycopersicum esculentum MILL.). Jurnal IImiah Membangun Desa dan Pertanian, 6(4), 144 - 148. doi:http://dx.doi.org/10.37149/jimdp.v6i4.21761

Received: November 19, 2021; Accepted: December 08, 2021; Published: December 12, 2021

\begin{abstract}
The study aimed to evaluate the inhibition of Trichoderma sp. associated with the leaves of the tomato plant (Lycopersicum esculentum Mill.). The research was carried out at the Plant Protection Laboratory of the Phytopathology Unit, Faculty of Agriculture, Halu Oleo University, Kendari. The study was arranged using a completely randomized design (CRD) with three types of pathogens, namely Collethotrichum sp., Schlerotium sp., and Paesilomyces sp., repeated five times. Observation parameters were the percentage of inhibition through multiple culture tests, secondary metabolites of volatile compounds, and nonvolatile compounds. The results showed that the ability to inhibit the fungus Trichoderma sp. against the fungal pathogen Colletotrichum sp. able be inhibited by $74.14 \%$ and $81.42 \%$ respectively in the volatile and nonvolatile secondary metabolite tests, while against the pathogen Sclerotium sp. able to be inhibited by $58.50 \%$ in the multiple culture test.
\end{abstract}

Keywords: inhibition, tomato leaf pathogen, tomato plant, Trichoderma sp.

\section{PENDAHULUAN}

Tanaman tomat memiliki tinggi nutrisi sehingga sangat digemari oleh masyarakat. Kebutuhan akan buah tomat sangat tinggi, namun produksi tomat diindonesia masih rendah. Produksi tanaman tomat rendah salah satunya disebabkan serangan patogen penyebab penyakit tanaman. Penyakit ini menyebabkan kerusakan pada tanaman tomat dengan kehilangan hasil lebih dari $80 \%$ diantaranya cendawan Alternaria sp., Helminthosporium sp., Sclerotium sp., dan Colletotricum sp. (Chandravanshi et al., 1994). Gejala penyakit yang ditimbulkan pada permukaan daun berupa bercak-bercak dengan diikuti perubahan bentuk dan warna pada daun. Patogen yang berasosiasi dengan tanaman tomat dapat menyerang pada daun, ranting, dan tangkai buah yang mengakibatkan kerugian secara kuantitatif maupun kualitatif. Gejala pada daun akan mengering dan buah menjadi rontok jika terjadi infeksi berat (Sumaraw, 1999).

Selama ini pengendalian yang dilakukan untuk penyakit tanaman masih bergantung pada pestisida kimia dengan cara menyemprot tanaman dengan fungisida secara teratur dan berjadwal. Penggunaan pestisida yang tidak taat aturan menyebabkan dampak negatif bagi kesehatan manusia, lingkungan, dan berkembangnya penyakit baru. Meningkatnya kesadaran manusia tentang keamanan pangan dan lingkungan, perlu pengendalian yang ramah lingkungan. Interaksi antara mikroba yang memiliki mekanisme antagonis mikoparasit dengan cendawan patogen menciptakan kondisi pertanian yang alami dan karenanya dapat mendorong produksi metabolit sekunder melalui molekul komunikasi dan interaksi tersebut (Speckbacher \& Zeilinger, 2018). Salah satunya cendawan antagonis Trichoderma sp. (Sumaraw, 1999).

Efektivitas agensia biokontrol sangat dipengaruhi oleh jenis agensia, cara aplikasi, dosis inokulasi dan mikroba lain (Asniah et al., 2013). Berdasarkan latar belakang perlu dilakukan evaluasi daya hambat Trichoderma sp. terhadap patogen yang berasosiasi dengan daun tanaman tomat (L. esculentum Mill.). 


\section{BAHAN DAN METODE}

Bahan yang digunakan dalam penelitian yakni cendawan patogen (Colletotrichum sp., Schlerotium sp., dan Helminthosporium sp.,), cendawan antagonis Trichoderma sp. (patogen dan antagonis merupakan koleksi Laboratorium Proteksi Tanaman), media agar dekstrosa agar (ADK), media agar dekstrosa cair (ADC), $\mathrm{NaOCl}$, aquades, etanol 70\%, spritus, plastik wrap, plastik sampel, tissu, kertas saring, label. Alat yang digunakan dalam penelitian terdiri dari, autoklaf, erlenmeyer 100 $\mathrm{ml}$, laminar air flow, gelas ukur, botol schott, cawan petri, lampu bunsen, jarum ose, cork borer, pinset, platform shaker, kaca preparat, kaca penutup, mikroskop binokuler, kamera, timbangan digital, hot plate.

Desain penelitian menggunakan Rancangan Acak Lengkap (RAL) sebanyak tiga perlakuan yakni Helminthosporium sp., Colletotrichum sp., dan Sclerothium sp. Setiap perlakuan diulang 5 kali sehingga keseluruhan 15 unit perlakuan.

\section{Persiapan Isolat Patogen dan Antagonis Trichoderma sp.}

Isolat patogen dan Trichoderma sp. yang tersimpan dalam lemari pendingin dilakukan penyegaran kembali pada media ADK dan diinkubasi pada suhu ruang.

\section{Uji Antagonis Trichoderma sp.}

Uji antagonis Trichoderma sp. terhadap cendawan patogen yang berasosiasi dengan daun tanaman tomat bertujuan untuk mengetahui daya antagonis yang terjadi pada setiap isolat yang dilakukan secara invitro mengunakan metode kultur ganda yang telah dimodifikasi (Singh \& Vijay, 2011) yaitu, biakan agensia hayati dan patogen berdiameter $5 \mathrm{~mm}$ diambil dengan menggunakan cork borer. Koloni patogen dan Trichoderma sp. ditumbuhkan secara berdampingan berjarak $3 \mathrm{~cm}$ pada setiap cawan petri. Selanjutnya inkubasi biakan pada suhu ruang $\left(27^{\circ} \mathrm{C}\right)$, diameter koloni diukur pada 3, 5 dan 7 hari setelah inokulasi (HSI).

\section{Uji Daya Hambat Metabolit Sekunder Senyawa Volatil}

Uji metabolit volatil, potongan koloni patogen dan antagonis diletakkan secara terpisah di tengah media PDA dengan mengikuti metode (Dennis \& Webster, 1971b),, yaitu dengan cara mengambil potongan biakan berdiameter $0,5 \mathrm{~cm}$ dari setiap biakan murni cendawan antagonis dan cendawan patogen, selanjutn Menangkupkan kedua cawan petri tersebut, dimana cendawan antagonis berada di atas dan cendawan patogen berada di bawah, saling berhadapan satu sama lain. Pertumbuhan koloni cendawan patogen pengamatan dengan cara mengukur diameter koloni biakan pada 7 HIS.

\section{Uji Daya Hambat Metabolit Sekunder Senyawa nonvolatil}

Pengujian senyawa metabolit non volatil, dengan cara mengambil satu potong setiap isolat cendawan antagonis berdiameter $0,5 \mathrm{~cm}$ diinokulasikan pada $100 \mathrm{~mL}$ media ADC dalam erlenmeyer berukuran $250 \mathrm{~mL}$. Sebagai kontrol digunakan media ADC saja. Cendawan antagonis dan kontrol pada media CDK ini diinkubasi pada platform shaker dengan suhu $27^{\circ} \mathrm{C}$ dan kecepatan $120 \mathrm{rpm}$ selama 14 hari (Dennis \& Webster, 1971a). Pada hari ke-14 inkubasi, ekstraksi dilakukan untuk mendapatkan supernatan dengan memisahkan air dengan biomassa miselium cendawan antagonis menggunakan kertas saring. Supernatan dari masing-masing suspensi cendawan diambil sebanyak 5 $\mathrm{mL}$ dan dicampurkan ke dalam media ADK sebelum media menjadi padat. Selanjutnya cendawan patogen dengan diameter $0,5 \mathrm{~cm}$ diletakkan di tengah media dan pengukuran diameter koloni dilakukan pada $7 \mathrm{HSI}$.

\section{Pengamatan}

Variabel pengamatan pada penelitian ini adalah persentase daya hambat dengan cara mengukur jari-jari pertumbuhan koloni patogen ke arah tepi cawan petri (R1) dan jari-jari pertumbuhan koloni patogen ke arah cendawan antagonis (R2). Persentase daya hambat (DH) cendawan antagonis dihitung dengan rumus:

$$
\mathrm{DH}=\frac{\mathrm{R} 1-\mathrm{R} 2}{\mathrm{R} 1} \times 100 \%
$$

Dengan: $\mathrm{DH}=$ Persentase Daya Hambat $(\%), \mathrm{R} 1$ = jari-jari pertumbuhan patogen ke arah tepi petri, $\mathrm{R} 2$ = jari-jari pertumbuhan patogen ke arah tepi isolat cendawan endofit. 
Kemampuan senyawa volatil dan non volatil dengan mengukur diameter pertumbuhan patogen pada perlakuan dan diameter pertumbuhan pada kontrol. Tingkat daya hambat relatif uji volatil dapat dihitung dengan rumus:

$$
\operatorname{THRv}=\frac{\mathrm{dk}-\mathrm{dp}}{\mathrm{dk}} \times 100 \%
$$

Dengan: $\mathrm{THRv}=$ tingkat hambat relatif uji volatil, $\mathrm{dk}=$ diameter patogen pada kontrol, $\mathrm{dp}=$ diameter patogen pada perlakuan.

\section{Analisis Data}

Data hasil pengamatan ditabulasi dan dianalisis menggunakan analisis sidik ragam (uji $F$ ) pada taraf kepercayaan $95 \%$. Apabila perlakuan berpengaruh nyata maka dilanjutkan dengan uji Beda Nyata Terkecil (BNT).

\section{HASIL DAN PEMBAHASAN}

Potensi cendawan antagonis Trichoderma sp. dalam menghambat pertumbuhan cendawan patogen Helminthosporium sp., Colletotrichum sp., dan Sclerotium sp. secara in vitro menunjukkan bahwa variabel pengamatan uji daya hambat berpengaruh sangat nyata pada uji kultur ganda dan uji senyawa volatile, namun berpengaruh tidak nyara pada uji senyawa non volatil. Presentase daya hambat cendawan Trichoderma sp. pada 3 patogen uji dapat dilihat pada Tabel 1.

Tabel 1. Persentase daya hambat (\%) Trichoderma sp. pada uji kultur ganda, senyawa volatil, dan senyawa non volatil terhadap cendawan patogen pada pengamatan $7 \mathrm{HSI}$.

\begin{tabular}{lcccc}
\hline \multirow{2}{*}{ Perlakuan } & & \multicolumn{3}{c}{ Persentase daya hambat (\%) } \\
\cline { 3 - 5 } & & Kultur Ganda & Volatil & Non Volatil \\
\hline Helminthosporium sp. & $\mathrm{x}$ & 28,44 & 45,44 & 78,08 \\
Colletotrichum sp. & $\mathrm{y}$ & $32,19^{\mathrm{b}}$ & $42,17^{\mathrm{b}}$ & 62,16 \\
& $\mathrm{x}$ & 0,00 & 74,14 & 81,42 \\
Sclerothium sp. & $\mathrm{y}$ & $2,87^{\mathrm{C}}$ & $59,54^{\mathrm{a}}$ & 68,57 \\
& $\mathrm{x}$ & 58,50 & 48,20 & 72,54 \\
\hline \multicolumn{1}{c}{ BNT $_{0,05}$} & $\mathrm{y}$ & $49,95^{\mathrm{a}}$ & $43,96^{\mathrm{b}}$ & 58,52 \\
\hline
\end{tabular}

Keterangan: Angka yang diikuti dengan notasi huruf berbeda menunjukkan perlakuan berbeda nyata berdasarkan uji lanjut $\mathrm{BNT}_{0,05} ; \mathrm{x}=$ data asli; $\mathrm{y}=$ data transformasi akar kuadrat $(\sqrt{\mathrm{x}+0,5})$

Tabel 1. menunjukkan bahwa persentase daya hambat cendawan antagonis Trichoderma sp. pada uji kultur ganda tertinggi diperoleh pada perlakuan patogen Sclerothium sp. dengan persentase sebesar $60,32 \%$ yang berbeda nyata dengan perlakuan lainnya pada pengamatan $7 \mathrm{HSI}$ dan menunjukkan penghambatan tertinggi pada patogen Colletotrichum sp. pada pengujian volatil dan non volatil yang berturut-turut adalah $74,14 \%$ dan $81,42 \%$. Kecepatan pertumbuhan cendawan antagonis pada uji kultur ganda diduga menjadi indikator terjadi kompetisi ruang dan nutrisi antara cendawan antagonis dengan patogen. Mekanisme penghambatan cendawan antagonis salah satunya dapat berkompetisi terhadap ruang dan nutrisi yang ditunjukkan pertumbuhan koloni yang cepat sehingga menghambat pertumbuhan koloni pathogen (Asniah et al., 2014).

Trichoderma sp. adalah salah satu agensia hayati yang mempunyai peranan sebagai pengendali penyakit, dan juga sebagai pemacu pertumbuhan tanaman. Kecepatan tumbuh suatu cendawan yang ditentukan dengan pertumbuhan koloni cendawan yang cepat merupakan salah satu indikator penting sebagai agensia hayati (Djafaruddin, 2000 dalam Amaria et al., 2015). Beberapa cendawan antagonis menunjukkan pertumbuhan yang lebih cepat atau lebih lambat dari pada cendawan patogen, hal ini mengindikasikan adanya persaingan antara cendawan antagonis dan patogen. Sudantha dan Abadi (2007) dalam (Manurung et al., 2014) yang menyatakan bahwa pertumbuhan cendawan patogen yang terhambat dapat diduga adanya beberapa mekanisme yang terjadi yakni kompetisi ruang (cendawan antagonis lebih cepat pertumbuhannya), mikoparasit (hifa cendawan antagonis melakukan penetrasi kedalam hifa cendawan patogen dengan cara membelit/melilit) dan antibiosis (cendawan antagonis menghasilkan senyawa antibiotik yang bersifat mudah menguap yang terdifusikan ke dalam medium). Penampakan penghambatan Trichoderma sp. terhadap patogen uji dapat dilihat pada Gambar 1. 


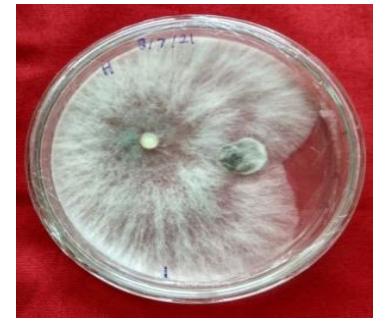

(a)

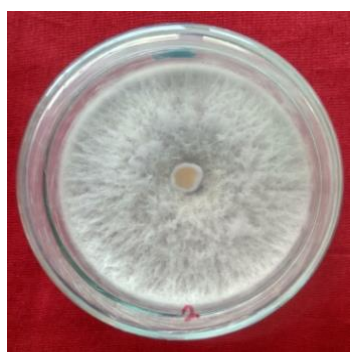

(d)

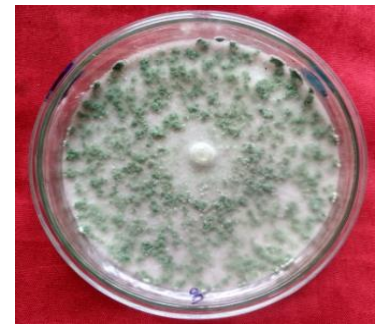

(g)

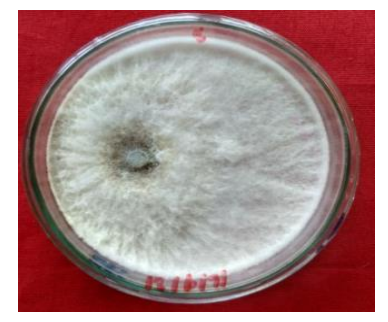

(b)

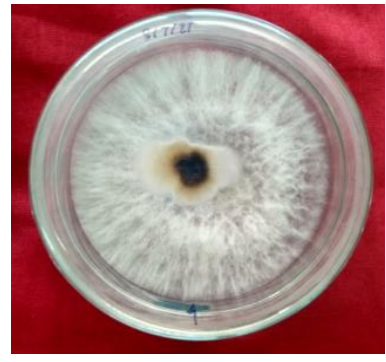

(e)

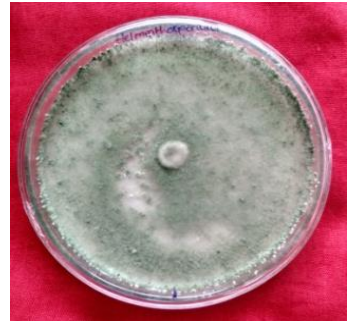

(h)

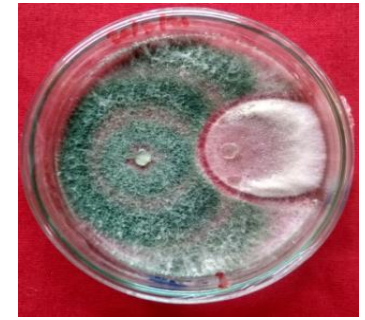

(c)

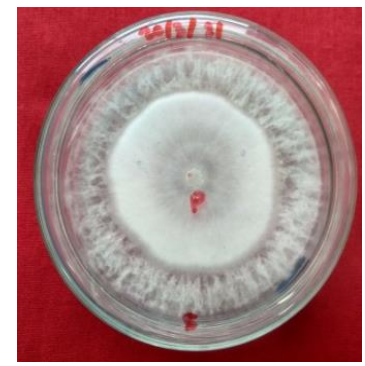

(f)

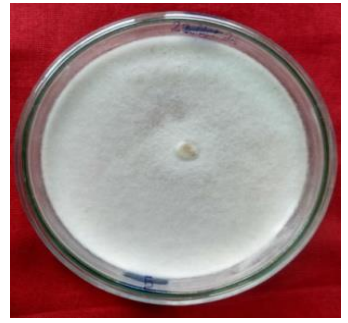

(i)

Gambar 1. Uji daya hambat cendawan antagonis Trichoderma sp. terhadap cendawan patogen (dari kiri ke kanan Helminthosporium sp., Colletotrichum sp., dan Sclerotium sp.). (a,b,c) uji kultur ganda, (d,e,f) Uji senyawa Volatil, dan (g,h,i) Uji senyawa Non Volatil.

Pengujian senyawa volatil menunjukkan bahwa cendawan antagonis dapat menghasilkan senyawa metabolit sekunder yang dapat menghambat pertumbuhan cendawan patogen. Penghambatan ini diduga suatu senyawa metabolit sekunder yang dikeluarkan oleh cendawan. Shehata et al., 2008 dalam Manurung et al., 2014 menyatakan bahwa salah satu ciri penting cendawan antagonis adalah memiliki pertumbuhan koloni lebih cepat dan menghasilkan senyawa antibiotik yang bersifat volatil (Ullah et al., 2020) atau nonvolatil (Ajith \& Lakshmidevi, 2010) yang dapat menghambat pertumbuhan cendawan patogen. Metabolit sekunder volatil atau nonvolatil dari cendawan antagonis dapat menghambat pertumbuhan koloni cendawan patogen (Chen et al., 2016). Cendawan antagonis yang berbeda akan menunjukkan perbedaan kemampuan dalam menghambat patogen. Kemampuan Trichoderma sp. menghambat pertumbuhan patogen sangat dipengaruhi jenis dan konsentrasi metabolit sekunder yang dihasilkan (Vinale et al., 2017).

\section{KESIMPULAN}

Kesimpulan dari penelitian ini bahwa kemampuan menghambat cendawan anatagonis Trichoderma sp. terhadap cendawan patogen Colletotrichum sp. sebesar $74,14 \%$ dan $81,42 \%$ masing-masing pada uji metabolit sekunder volatil dan non volatil, dan terhadap patogen Sclerotium sp. sebesar $58,50 \%$ pada uji kultur ganda. 


\section{UCAPAN TERIMA KASIH}

Terima kasih disampaikan kepada Badang Litbang Pertanian Kementerian Pertanian RI atas dukungan dana melalui Penelitian Kemitraan sesuai surat perjanjian pelaksanaan kegiatan Nomor : 504.4/PL.040/H.1/03/2020.K Tanggal: 26 Maret 2020. Ucapan yang sama disampaikan kepada LPPM Universitas Halu Oleo atas dukungan selama kegiatan serta terima kasih disampaikan kepada mahasiswa dan petani yang membantu dalam penelitian.

\section{REFERENSI}

Ajith, P., \& Lakshmidevi, N. (2010). Effect of Volatile and Nonvolatile Compounds from Trichoderma sp. Against Colletotrichum capsici Incitant of Anthracnose on Bell Papers. Nature and Science, 8(10), 265-269.

Amaria, W., Harni, R., \& Samsudin. (2015). Evaluasi jamur antagonis dalam menghambat pertumbuhan rigidoporus microporus penyebab penyakit jamur akar putih pada tanaman karet. J TIDP, 2(1), 51-60.

Asniah, A., Widodo, W., \& Wiyono, S. (2013). Potensi Cendawan Asal Tanah Perakaran Bambu Sebagai Endofit Dan Agen Biokontrol Penyakit Akar Gada Pada Tanaman Brokoli. Jurnal Hama Dan Penyakit Tumbuhan Tropika, 13(1), 61-68. https://doi.org/10.23960/j.hptt.1136168

Asniah, Lestari, D., Mariadi, \& Darlian, L. (2014). Potensi cendawan endofit nonpatogen asal akar tanaman cabai (Capsicum annuum L.) sebagai biofungisida patoge Fusarium oxysporum. Agriplus, 24(2), 177-183.

Chandravanshi, S., Singh, B., \& MP, T. (1994). Persistence of Different Fungicides Used Against Alternaria Alternata In Tomato. Indian Phytopathol, 47, 241-244.

Chen, J. L., Sun, S. Z., Miao, C. P., Wu, K., Chen, Y. W., Xu, L. H., Guan, H. L., \& Zhao, L. X. (2016). Endophytic Trichoderma gamsii YIM PH30019: A promising biocontrol agent with hyperosmolar, mycoparasitism, and antagonistic activities of induced volatile organic compounds on root-rot pathogenic fungi of Panax notoginseng. Journal of Ginseng Research, 40(4), 315-324. https://doi.org/10.1016/j.jgr.2015.09.006

Dennis, C., \& Webster, J. (1971a). Antagonistic Properties Of Species Groups of Trichoderma I, Production Of Nonvolatile Antibiotics. Trans Br Mycol Soc, 57, 25-39.

Dennis, C., \& Webster, J. (1971b). Antagonistic Properties of Species Groups of Trichoderma II, Production Of Volatile Antibiotics. Trans Br Mycol Soc, 57, 41-48.

Manurung, I., Mukhtar, R., \& Lahmuddin, L. (2014). Uji Antagonism Cendawan Endofit terhadap Cercospora oryzae Miyake dan Curvularia lunata (Wakk) Boed. Dari Tanaman Padi di Laboratorium. Jurnal Online Agroteknologi, 2(4), 156-1571.

Shehata, Fawzy, S., \& Borollosy, A. (2008). Induction of Resistance Against Zuccini Yellow Mosaic Potyvirus and Growth Enhancment of Squash Plants Using Some Plant Growth Promoting Rhizobacteria. Australian Journal of Basic and Applied Scienes, 2, 174-182.

Singh, P., \& Vijay, K. (2011). Biological Control of Fusarium Wilt Of Chrysanthemum With Trichoderma And Botanicals. J. Agric Tech, 7(6), 1603-1613.

Speckbacher, V., \& Zeilinger, S. (2018). Secondary Metabolites of Mycoparasitic Fungi. Secondary Metabolites - Sources and Applications. https://doi.org/10.5772/intechopen.75133

Sumaraw, S. (1999). Periode Kritis Tanaman Tomat Terhadap Serangan Alternaria Solani (Ell. \& G. Martin) Sor. dan Faktor Penentunya. Buletin Hama Dan Penyakit Tumbuh, 11(2), 67-72.

Ullah, A., Bano, A., \& Janjua, H. T. (2020). Microbial Secondary Metabolites and Defense of Plant Stress. In Microbial Services in Restoration Ecology (pp. 37-46). Elsevier. https://doi.org/10.1016/b978-0-12-819978-7.00003-8

Vinale, F., Nicoletti, R., Lacatena, F., Marra, R., Sacco, A., Lombardi, N., d'Errico, G., Digilio, M. C., Lorito, M., \& Woo, S. L. (2017). Secondary metabolites from the endophytic fungus Talaromyces pinophilus. Natural Product Research, 31(15). https://doi.org/10.1080/14786419.2017.1290624 